\title{
Being human in the shadow of racism
}

\author{
Joël Mbongi Kuvuna \\ University of KwaZulu-Natal, Durban, South Africa \\ joelkuvuna@gmail.com \\ Rudolf von Sinner \\ Stellenbosch University, South Africa \\ r.vonsinner@est.edu.br
}

\begin{abstract}
This paper is inspired by the experience of a black student who underwent racist treatment in Brazil. Nowadays, racism may appear in any societal structure. Misuse of power is one of the causes of violence and racism. A person who finds him- or herself in a position of some power may, while acting in the name of "law", turn into an incarnation of the law. This paper wishes to speak out on matters of violence, oppression and racism which are spreading in society. The faces of racism need to be shown, even where racism is institutionalized.
\end{abstract}

Key words

Racism; humiliation; oppression; human dignity

\section{Introduction}

Violence, oppression and racism are present, and even spreading, in the contemporary world. One way of handling this reality is to ignore it. However, the theologians James H. Cone, Bonhoeffer and Martin Luther King Jr. have expressed their refusal to keep silent about the great moral issues of the time. They have used the injustice in society to challenge the notion of religious meaning. They did not allow things to happen unopposed. They fiercely protested against Nazi and American racism. Racism was presented as a major killer in the modern world (Cone 2004b:140).

In his consideration of racism, Leiba poses that racism is a mental disorder, as people suffering from paranoia project their unacceptable fears and ideas on other people (2012:22). Citing Colon, Chaney defines racism as: 
The subordination of any person or group because of skin colour or other distinctive physical characteristics. It can be reflected in both individual and institutional acts, decisions, habits, procedures, and policies that neglect, overlook, exploit, subjugate, or maintain the subordination of the individual or the group (2015:313).

Scholars suggest that the experience of racism is multi-dimensional and classify racism using a tripartite typology, consisting of individual racism, institutional racism and cultural racism (Chao et al., 2014:260).

Racism can be seen as institutionalized when it is associated with specific policies or procedures of institutions and when law-enforcement agencies are involved. Institutionalized racism may be embedded in government, business, schools, churches, etc., and such racism consistently results in the unequal treatment of particular groups (Chaney 2015:313). It implies that the settings for racism may occur in any societal structure, even in the church, as was evident in South Africa at the time of apartheid when Scripture was used to enforce the separation of black and white. It is still apparent today as when many churches, worldwide, are characterised by the skin colour of their followers. In South Africa as well as in other countries, mixed churches are randomly found. Often a church is attended either by whites or by blacks. In his writing on communion ecclesiology in a racially polarised South Africa, Resane states that, "in South Africa, communion ecclesiology cannot be experienced when the church is silent to evils of colonialism, apartheid, corruption, etc." (2017:7).

Cone speaks on the imposition by the Europeans of cultural and religious imperialism and, what he calls, "the racist value-system", on people of colour, forcing them to believe that the only way to be a civilized human being is to be white and Christian. Thus, the oppressed were pressurized to behave and to become like their oppressors (Cone 2004a:141). At the same time, they were perceived as being incapable of becoming like whites. Therefore, they should simply resign themselves to occupying subordinate positions.

In 2015, black women, marching in Brazil, stated:

We experience the most perverse racism and sexism by virtue of being black and women. We daily face white supremacy and 
patriarchy and sexism, which constitute a system of oppressions that prompts black women to fight for their own survival and the survival of their communities. Despite our contributions, we have been the targets of all kinds of discrimination for generations and generations (Medeiros 2016:76).

Denouncing the police, women formed groups to defend themselves against police brutality.

The objectives of the present study are:

- To uncover the racism that is part of a worldwide narrative.

- To face the abuse of power and promote human dignity by exposing the inherent and limitless worth of every human being.

\section{The story of a black African student}

The $21^{\text {st }}$ of October 2016 was the final day of an intercontinental Ph.D. seminar held in São Leopoldo in Brazil and devoted to the topic: "On becoming human-impacting communities: Gender-Race-Politics". Faculdades EST in São Leopoldo was hosting the seminar. Participants were the Union Theological Seminary (USA), the University of Oslo (Norway) and the University of KwaZulu-Natal. At the end of the seminar, a scene occurred that demonstrates the continuing challenge posed by racism, violence, oppression and dehumanization in the contemporary world.

With the conference concluded, the delegations from the USA and Africa left together as they were booked on the same domestic flight from Porto Alegre to São Paulo where they would join international flights. At Porto Alegre Airport, the two professors from the USA and their two doctoral students, as well as the single black doctoral student from Africa, checked in and everything seemed alright. There was no hint of any irregularity. When the group of academics was on the point of leaving the check-in facility, three men in civilian clothes appeared, displaying the aggressive, violent and overbearing behaviour that one would expect from gangsters. Their tone was brutal: "We are police. Don't move and hand over your passports!" The delegation was at first unruffled. They had no need to fear the police. After all they were, every one of them, respectable academics. They held out their passports and were told to follow the officers. 
When they attempted to ask what was wrong and where they were taken, one of the men began to provide an explanation but was cut short by another who said: "You don't have to answer them". It was a frightening moment. They were made to enter the innermost part of the federal police office and it began to feel like being in custody. One black American asked: "What law did we break to be forced like this?" There was no response, but the policemen took the laptop bag of the African and checked it over and over. One of the Americans offered the men his laptop bag, but they said: "Not that one".

After a while, a lady brought the African's luggage that had earlier been checked in and that should already have been in the aircraft's hold. The African realised now that he was the target of this operation. He was asked to open the padlock on his bag. At the same time the Americans were urged to leave and be on their way. When they resisted, one of the policemen said: "What do you think? If you resist, we will show you that you are here in Brazil!" The black African said loudly: "Why must they leave and why can't I go? What's wrong with me?" A black American colleague turned furiously to the policemen: "I know why. It's because I'm black but American and he is a black African". Looking at the African, he added sadly: "Sorry my brother, we are with you". When only the African was left, the policemen ransacked his bag, piece by piece, turning it over, and fetched a big dog to sniff at the contents. When the dog found nothing, it was led out of the room, but they called it back three times to repeat the sniffing. One policeman studied a bottle of lotion from the bag and said with disdain: "African lotion!"

Finally, the African was told to take off his clothes. Again, the dog was called, this time to sniff at the African. Thereafter the African got dressed and was told to gather his belongings that had been dispersed all over the room. The policemen returned his passport and told him to get out. No apology was offered. The African found his colleagues waiting at the door. He cried out: "I'm sorry to be an African. But I'm proud of who I am." All his colleagues showed him solidarity which did give him some comfort. The experience has been an important lesson for this black student. It gave him the opportunity to increase his awareness of the state of the world in many ways. 
Analysing the story, the following questions arise. Why were only the black American and the black African targeted? Why did the police give up on the first as soon as they saw that he carried an American passport? Probably, the initial reason for the special treatment was skin colour, in other words simple "racism". Quoting Martin Luther King Jr, Kuvuna argues that, "Now is the time to lift our national policy from the quicksand of racial injustice to the solid rock of human dignity" (2015:78). In his books Black Skin, White Mask (1952) and the Wretched of the Earth (1961), Fanon examines the impact, including the psychological consequences, of racism in respect of both the oppressor and the oppressed.

\section{Methodology}

The methodology applied in this paper is concerned with a consideration of the African student's narrative and how, in that context, violence did occur. The experience of the oppressed can open the way to an understanding of the issue of human dignity abuse and how it figures in the development of the theology of liberation. This paper focuses on some key words and sentences in the narrative. Freire's Pedagogy of the oppressed and Fanon's Psychology of the oppressed advocate the need to face the abuse of power by relying on human dignity.

A reflection on Freire's views leads us to affirm that,

If students are not able to transform their lived experiences into knowledge and to use the already acquired knowledge as a process to unveil new knowledge, they will never be able to participate rigorously in a dialogue as a process of learning and knowing (2005:19).

In fact, it is not only for students to learn of daily experiences. All of us should use the opportunity to learn from daily experiences, be they good or bad. The black student's treatment on the Brazilian airport is not presented as final or close-ended, but rather as opening the way to learning. In his writings Harvey argues that,

Learning from victims of oppression is an often informal educational mode of undermining future oppression and both the listener and the speaker can be seen as engaged in resistance (2010:16). 


\section{Discovering the shadows of racism}

The experience of racism can be used in many ways, individually or structurally, according to plans or spontaneously. The following four practices present some examples of the shadowy appearance of racism.

\subsection{Abuse of human dignity}

The abuse of human dignity is understood as the dehumanization of a human being. Dignity has been described as the minimum of value that has to be ascribed to the individual in order to allow him or her a life as an authentic being. Discussing human dignity, Moltmann argues that dignity is bestowed, not by a person or by any human institution, but by God the creator (1984:X). In line with Moltmann's thinking, Kuvuna stresses that the many individuals and organisations concerned with human dignity are not the inventors of the notion. God's claim to creation is the origin of dignity. God created humankind ex nihilo (from nothing), which reinforces the special relationship God claims to his creation (Kuvuna, 2015:69).

To deny or suppress individuality, personhood and humanity, constitutes an abuse of dignity that may lead to rebellion and even suicide. Oprisko defines the rebel as an honourable individual who seeks to restore his dignity and the dignity of others who share the rebel's troubled experiences (2012:130). The pre-modern idea that respect for dignity is to be granted only to those human beings who rank highly in society, currently seems to have been overcome, along with its limiting perspective. Moltmann's comprehension of humankind as imago Dei is linked etymologically with the word kabod derived from the root "kbd", and indicating heaviness in the physical sense and honour or respect in the spiritual sense (Kuvuna, 2015:70). It means that God did enter in the creation once it was made and had a close relationship with humankind. Mysterion thus becomes the image where God dwells.

In a discussion of the protection of human identity and worth, Moltmann concludes that each violent act committed by human beings against fellow beings, or by human beings against feeble creatures, constitutes sin and is a crime against life or humanity. He thus qualifies violence as a sinful act against God's will. The perpetrators of violence tend to become increasingly unjust and inhuman while their victims are robbed of their rights and become dehumanized (Moltmann, 1994:4). 


\subsection{Humiliation}

When, in the above narrative, the police interviewed the black African student, he felt, as he states, deeply humiliated as a person. He felt that he was not recognised as a full human being who deserves respect. Clearly, the policemen thought of themselves as superior to him.

Statmann discusses the close links between humiliation and dignity (2000:524). If dignity is to be ascribed to all human beings, humiliation implies the lack of acknowledgement of such dignity. It represents the reality of denying the other the fact of his or her belonging to humanity in the fullness of its existence. Interpreting the notion of humiliation in the context of dignity, Shultziner states that, "the humiliation of the individual causes the humiliation of the entire human race" (2006:670). In relation to an African cultural background, the occurrence of a person being humiliated and exposed naked in public will be the shame not only of that man or woman, but of all those surrounding him.

\subsection{Violence}

In the context of this paper, violence can also be considered as one of the faces of racism. In his study of Young, Dubrosky argues that violence gains legitimacy when it is tolerated and remains unchallenged, or when the perpetrators of violence are lightly reprimanded, if at all (Dubrosky 2013:208). Poltera, on the other hand, associates violence with social justice (2011:237). As in the time of apartheid, even churches may work with the state in order to legalise racism. In such a context, violence can become justified if violent acts are in compliance with law and order. Thus, in the case of the Brazilian policemen holding up the black African, one of them argued: "I'm doing my job". Whatever is done in the line of duty can, thus, be justified as being legally correct. This however may also constitute a root of evil in society. It allows the oppressor to think that violence stops being violence if it is committed in the name of a job or for some institutionalised reason.

Thinking along these lines, violence itself threatens to become merely "a job". And for a job well done the worker deserves to receive congratulations, encouragement and payment. This is an exact reflection of Chaney's findings when studying a case of police violence against civilians in the USA. One of the respondents in the study reminded all participants that 
being aggressive was part of his job as well as a tool for self-defence in law enforcement and he added: "I guess most police departments are a little aggressive" (Chaney 2015:315).

\subsection{Oppression}

Freire argues in his study that those who oppress, exploit and rape by virtue of their power, are unable to find in this power the strength to liberate either the oppressed or themselves (2005:44). According to Harvey's conception, oppression can show a civilised face when it is so-called based on law or executed in the name of a duty or job that perpetrators are involved in while oppressing others (2010:13). Violent or not, the oppression to which a victim is exposed, is experienced as mistreatment and dehumanization. The oppressed distinguish between non-violent and violent oppression, and so it appears that oppression wears different faces. Two of these faces are mistreatment and dehumanization and both constitute abuse of human dignity.

In a study of Young, Dubrosky defines oppression as a disadvantage and injustice suffered by some people, not necessarily because they are coerced by a tyrannical power, but because of everyday practices in a well-intentioned liberal society. This points to the existence of structural phenomena that immobilize a group and diminish its strength (Dubrosky, 2013:205-206).

Scholars are of the view that oppression always damages human identities by depriving people from opportunities while oppression frequently has also a different, secondary destructive impact. According to Harvey, a person's identity is twice damaged by oppression in cases where they internalize the dismissive views that other persons may have of them (2010:18). Dubrosky (2013:206-208), reporting on Young's study of oppression, mentions that Young distinguishes the following five faces of oppression.

\section{Exploitation}

Some people exercise their capacities by coercion, under the control, according to the purposes, and for the benefit of other people.

\section{Powerlessness}

This is the state of someone experiencing disrespectful treatment because of his or her perceived status. Many people judge others according to the group to which they belong. It is this belonging that determines, according 
to members of other groups, whether they are strong or weak and worthy of respect. The above-mentioned African student was perceived as weak or inferior because of his colour and because his Congolese passport differentiated him from whites and USA blacks.

\section{Marginalization}

It results from a lack of self-respect. It involves a distributive judgement that considers others as less worthy. Marginalization is the consequence of both a lack of consideration for others, perceiving them as unworthy.

\section{Cultural imperialism}

This is understood as the process in which the norms and the culture of a dominant group get imposed as the dominating and general norm and culture. The dominant group continues to reinforce its position by ensuring that its domain controls other groups and domains (Dubrosky 2013:207).

\section{Violence}

As argued above, violence is a form of racism. It can also take the form of an institutionalised system of oppression.

\section{Why do people oppress others?}

Mostly, perpetrators of violence misuse their power or are ignorant of who they really are. The experience of the African black student confirms that here the combination of the supposed superiority of the oppressor and his misuse of power are at work. His authoritarian legality is used in the name of his job to manipulate and oppress his victim.

Such behaviour sometimes results from an elusive perception of one's own status. When the black American tries to support the black African, one of the policemen sneers: "What do you think ... If you resist, we show you: we are here in Brazil." This is an authoritarian declaration of someone who feels he has plenty of power and is able to do whatever he wants whenever he wants. He is in his comfort zone, sure of his power. "We are in Brazil!" It may be a show of the arrogance of some Brazilian policemen: "Here, in our country, we behave as we want". It reminds of the arrest of Jesus when Pilate tells him: "Do you not know that I have power to crucify you and power to release you?" (Luke 19:10). Thus, the man who has power turns into an incarnation of the law. 
One of the American academics asks in vain: "Tell us which law we have broken?" A policeman answers: "We do our job". Here the committing of violence becomes a question of law. Law takes on confusing aspects when people consider themselves as its embodiment. At the same time, how can the law function if there is a lack of people enforcing it? Conscientious people are needed to maintain the law and give it power. In the case of the Brazilian airport police, they were expected to follow the law, but in what manner? Human rights might not be limited to simply a human rights concern. The event that motivated the present paper was a human rights group who reported a case of racism.

As the African student was allowed to leave, one of the policemen said: "Your colleagues are waiting outside, and they are furious. Tell them not to behave like this towards the police. Because we can let them miss their flight". This assertion clearly was a show - or at least a pretence - of power that in certain circumstances can be exercised over civilians. Again, it suggests abuse of power.

This raises the question of how to face and deal with the abuse of power if it involves the ignoring of human dignity.

\section{Facing the abuse of power: Freire and Fanon}

Freire offers in his Pedagogy of the oppressed no so much solutions for the oppressed, but rather attempts to work with them by proposing that they reflect on the possible causes of oppression and find a way towards liberation. The central question is how to deal with abuse in all its different forms. Freire states that only a power, springing from the weakness of the oppressed, can be strong enough to free both the oppressor and the oppressed (2005:44). He looks, in other words, not only for the liberation of the oppressed, but he sees both the oppressed and the oppressor as being in need of freedom.

Fanon recognises violence as a seed that has been put into the heads of natives by their oppressors (Fanon, 1977:86). Based on Fanon's thought, sudden bursts of violence may be no surprise because, in Fanon's understanding, the seed of violence grows when human beings appear to be dehumanized and when violence takes the place of human dignity. 
Interpreting Fanon's viewpoints in Psychology of oppression Bulhan understands that Fanon sees the use of violence as playing a liberating role in situations where all other means of resistance have failed. Being himself committed to the Algerian war of liberation, Fanon was anxiously looking forward to seeing the Algerians free from oppression. He eventually turned to the perception that "only violence could transform the oppressive order and occupied psyches" (Bulhan, 1985:139-140). He concluded that revolutionary violence was a means of securing freedom. As concerns Fanon's social and political thought, he describes violence as "a cleansing force". It is a force that frees colonized people from feelings of inferiority and humiliation and restores them to their fullness as human beings (1977:121).

Many scholars argue that Fanon's theories were influenced by the racism he experienced in France. From the viewpoint that people are social beings, it is clear that racism and social tensions may cause stress and affect mental health, Fanon proposes a mainstream psychiatric education and argues that one must understand human problems as being cultural in nature and look for a social order that leads to change (Leiba 2012:22).

Freire's Pedagogy of the Oppressed mentions the discovery of, what is called, the cycle of oppression. Freire describes that the struggle of the oppressed to obtain liberation may turn them into oppressors themselves. To be like their oppressors becomes their ideal of humankind. They come to see the oppressor as a true and optimal human being, as the model of humanity. This phenomenon - the cycle of oppression - derives from the fact that the oppressed, at a certain moment of their existential experience, choose to adopt an attitude of "adhesion" to the oppressor (Freire 2005:45).

Thus, being oppressed can bring about more oppression when the cycle of oppression kicks in. Violence may be planned, structural, or sudden, even to those who are executing it. It may also be experienced as sudden by the victims. From the perspective of those who are oppressed or have experienced violence, committing violence may be aimed at protecting their human dignity or serve as a way to satisfy a need for vengeance. People who have been violated, do, on occasion and involuntarily, turn violent themselves. 
Another response to racism and to all kinds of oppression is offered by the non-violent option, advocated by Martin Luther King jr. who understands human beings as bound together and inseparably linked to a common humanity. What we do to one another, we do to ourselves. That is why King was absolutely committed to non-violence (Cone 2004a:141-142). Bayard Rustin's moral conviction, as presented by Sarah Azaransky, accentuates the option of non-violence. He urges for the practice of non-violence to be adopted and encourages witnessing God's presence and, when necessary, to loyally oppose the government and those in power who have committed violence. He promotes peace, equality, integrity and simplicity. Rustin denies that violence, or preparing to commit violence, can ever sow the seeds of peace (Azaransky 2016:4). He is concerned that depending upon violence may smother the spark of God that is present in every human being.

Analysing oppression as a system, Harvey refers to many possible ways of resistance, because oppression itself characteristically takes on many different faces. According to Harvey's study, the first "strategy of resistance" is based on education, both formal and informal (2010:16). Education consists in the acquiring of knowledge through teaching and learning. Without adequate instruction people remain imprisoned in ignorance as if in a deep well.

Victims should also speak up, explain their concerns and protest, thereby making an irreplaceable contribution to the lessening of oppression (Harvey 2010:17). According to, among others, Laurence Thomas, victims of violence have a responsibility for getting involved in furthering awareness of oppression (Harvey, 2010:26). No method is given for resisting oppression. Resistance can take many forms, depending on the kind of oppression concerned and how it manifests itself.

In my view, writing on oppression is also a way of resisting it. Resistance may also involve the building of relationships with people who willingly contribute to oppression, instead of confronting them with hostility (Harvey 2010:25). The oppressors and the oppressed are both in need of education. 


\section{Discovering humanity to mitigate racism}

Generally, a human being may be described as:

- Whoever can understand the humane in other human beings of any race or origin;

- whoever can interact with others - interracial, intercultural and interreligious; whoever understands that he or she is not the only being in existence. This means that he or she has learned to respect the space of others.

In order to become such a human being two steps are proposed, the first step for the oppressed and the second step for the oppressor.

\section{The oppressed}

In relation to the oppressed, two points are important for maintaining their humanity in the face of racism.

- Secure relationship. The above described experience of the black African student indicates that, in the moments of his oppression, his spirit was strengthened by the support shown by his companions. Based on his own experience, Poltera concludes that oppressed people can be silenced if they belong to a powerless group. Being powerless, they may easily become intimidated and get the feeling that nobody listens to them. In addition, oppressed people can be silenced even as they speak out, because what they say fails to "achieve the effects that they intend". Besides, agents may be silenced if, when speaking out, their words fail to trigger the very action they hoped for (2011:244). The power of sure and secure relationships is one of the certainties that may comfort the oppressed when they feel humiliated and violently abused. While resisting oppression, exploring one's individuality is as important as being in solidarity with other oppressed people (Harvey 2010:20).

- Discovering one's identity is to make sure of who one really is. When the African student comes to the end of his ordeal and, leaving the custody room, finds his colleagues waiting, he cries out: "I'm sorry to be African ... But I'm proud of who I am". As Kuvuna (2015:81) notes, referring to the victims of humiliation and abuse, they distance themselves from the values and standards of their abusers. 
The victims of abuse may feel that having been humiliated positions them lower than, and makes them inferior to, their abusers. In that case the important thing is to maintain the level of one's self esteem. When one's dignity is in question, the challenge is to not let one's self-respect depend on the perceptions of one's opponent. Even if the opponent accords one no respect whatsoever, one should never doubt one's worthiness of respect in accordance with one's inherent value. It is what Chao et al call a matter of self-esteem. Self-esteem refers to an individual's overall evaluation or appraisal of his or her worth and it encompasses beliefs about oneself as well as emotions. It is determined by how people feel positively about themselves and their competences (2014:260). The black student from Africa illustrates the point when he says: "I'm proud of who I am". Such high self-esteem is closely related to his racial identity, as Mahalik et al, quoted in Chao (2014:260), argue. But in that study, they also show that levels of self-esteem may depend on levels of perceived racism. The higher the degree of perceived racism, the lower one's self-esteem. Self-esteem affects our relation to others. Scholars think that persons with a high self-esteem tend to maintain a good quality existence and suffer less psychological distress.

Quoting D. Lange, De Villiers writes: "People's dignity does not rest in their rationality as Kant saw it, nor on their social merits, but on the fact that they are called by God to live their lives as creatures coram Deo, together with others. Their self-respect is implied by and derived from this vocation" (2010:267). In his Pedagogy of the Oppressed, Freire discusses what often holds people in a situation of oppression. It is the definition that people give of what it means "to be". Often people define their existence in comparison to that of others. "I am because I look like...”. It is an incorrect way to define existence. In his argument Freire states:

As long as they live in the duality in which to be is to be like, and to be like is to be like the oppressor. The pedagogy of the oppressed is an instrument for their critical discovery that both they and their oppressors are manifestations of dehumanization (2005:49). 


\section{The oppressors}

Oppression demonstrates ignorance of what a human being is. From the racist perspective the value of human beings depends on their skin colour, place of settlement, etc.

The human body is the place where God meets each human being who therefore, deserves the kabod of God and the respect of neighbour. Thus, human beings have inherent and unlimited worth. Their worth does not depend on race, sex, the area where they live or anything else. It is an inner value that cannot be destroyed by external conditions. It can however be abused by external agents. Our brand of humanity leads us to consider other human beings as part of us. It means that, when somebody is unaware of this dimension and doesn't take account of his or her own humanity as being extended to include the humanity of others, something is wrong. Only humanity can connect one human being to another. The oppressor may be seen as affected by such a failing. It keeps him imprisoned in his own world and to be liberated he will need to heal his ego.

Human relationships in society are determined by the way in which people communicate, respecting each other's dignity and honour. Jesus taught his disciples by example, treating everyone as possessed of equal dignity and honour. Nolan argues that equal dignity, respect and honour must be shown to every human being because all are made in the image and likeness of God (2009:106).

According to Nolan, respect for human dignity is the basis of love and justice in social relationships. In the confrontation of the travelling academics with the Brazilian airport police, the question of the black American - "Which law did we break?" - is left unanswered. The truth is that in all areas of life, law has no place if respect for human dignity is lacking. Inequality permeates not only the structures of our society, but also the structure of our thinking (2009:107).

\section{Conclusion}

This paper has been written in order to awaken people's conscience to the shadowy presence and the many faces of racism. The paper describes how a black African student experienced racism. 
Racism occurs in any societal structure in various ways. It can be manifest in the abuse of the human value ascribed to individuals as authentic beings. It may be evident in the humiliation, violent treatment and oppression of people. Mistreatment and dehumanizing acts may diminish human dignity and damage people in their sense of identity.

Different causes can be found for oppression such as the misuse of power by people who consider themselves as an incarnation of the law and who ignore the identity of others.

Based in part on Freire's Pedagogy of the oppressed, this paper enforces the perception that the weakness of the oppressed is capable of generating sufficient power to free both themselves and their oppressor, even if, according to Fanon, the oppressed sometimes turn to the use of revolutionary violence to gain freedom. Freire's arguments demonstrate that such violence may end up by creating a cycle of violence. For working towards a better world where racism and other forms of dehumanization have no place, the present paper relies on the non-violent option of resistance by embracing education, the discovering of one's identity, and the building of secure relationships by the oppressed.

\section{References}

Azaransky, S. 2016. “That Spark of God in Each of Us.” Bayard Rustin's Moral Vision. Union Theological Seminary

Bulhan, H.A. 1985. Frantz Fanon and the Psychology of oppression. New York: Plenum Press.

Chaney, C. 2015. Institutional Racism: Perspectives on the Department of Justice's Investigation of the Ferguson Police Department. Western Journal of Black Studies. 39:312-330.

Chao, R. C.-L., Longo, J., Wang, C., Dasgupta, D. \& Fear, J. 2014. Perceived Racism as Moderator between Self-Esteem/Shyness and Psychological Distress among African Americans. Journal of Counselling \& Development. 92:259-269.

Cone, J.H. 2004a. Theology's great sin: silence in the face of white supremacy. Black Theology: An International Journal. 2:139-152. 
- 2004b. Theology's great sin: silence in the face of white supremacy. Equinox Publishing 2.

Dubrosky, R. 2013. Iris Young's Five Faces of Oppression Applied to Nursing. Nursing Forum. 48:205-210.

Fanon, F. 1952. Black Skins, White Masks. New York: Grove Press.

- 1961. The Wretched of the Earth. New York: Grove Weidenfeld.

- 1977. Social and political thought. Columbus: Ohio State University Press.

Freire, P. 2005. Pedagogy of the oppressed. New York: Continuum.

Harvey, J. 2010. Victims, Resistance, and Civilized Oppression. Journal of Social Philosophy. 41:13-27.

Kuvuna, J.M. 2015. Building a Human Rights Culture in the Context of Child Soldiering: A Challenge to the Protestant Church in the Democratic Republic of Congo. Master: University of KwaZulu-Natal.

Leiba, T. 2012. Mental scars of racism. Nursing standard. 27.

Medeiros, C.F. A.A. 2016. March against Racism and Violence and in Favour of Living Well (bem viver): Brasilia 2015 National Black Women's March, November 18. Meridians: Feminism, Race, Transnationalism. 14:76-83.

Moltmann, J. 1984. On human dignity. Political, Theology and Ethics. London: SCM Press.

- 1994. Justice for victims and perpetrators. Reformed world. Vol 44.

Nolan, A. 2009. Hope in an age of despair. USA: Orbis books.

Oprisko, R. 2012. The Political Theology of Dignity. Revista pléyade. 119-136.

Poltera, J. 2011. Violence and Silencing: A Philosophical Investigation of Apartheid. Critical Horizons. 12:232-250.

Resane, K.T. 2017. Communion Ecclesiology in racially polarised South Africa. Bloemfontein: Sun Press. 
Shultziner, D. 2006. A Jewish conception of human dignity: Philosophy and its ethical implications for Israeli Supreme Court decisions. Journal of Religious Ethics. 34:663-683.

Statman, D. 2000. Humiliation, dignity and self-respect. Philosophical Psychology. Vol 13.

Villiers, E.D. 2010. The recognition of human dignity in Africa:

A Christian ethics of responsibility perspective. Scriptura 104:263278. 